J. Product. \& Dev., 17(2): 193-209(2012)

\title{
SOMATIC EMBRYOGENESIS AND PLANT REGENERATION INDUCED FROM MATURE SEEDS, COTYLEDONS AND SHOOT TIPS OF CUCUMBER.
}

\author{
El-Sayed El-Absawy1, Yehia A. Khidr2*, Amal Mahmoud2, Mohamed E. \\ Hasan1 and Alaa A. Hemeida1 \\ ${ }^{(1)}$ Department of Bioinformatics, ${ }^{(2)}$ Department of Plant Biotechnology, Genetic \\ Engineering and Biotechnology Research Institute, Sadat City, Menofia University. \\ *Corresponding author: yehia.khidr@yahoo.com
}

\section{ABSTRACT}

Commercial cucumber cultivars were explored for embryogenesis and plant regeneration induced in somatic tissues on plant growth regulators. An efficient in vitro regeneration protocol for Cucumis sativus $L$ via somatic embryogenesis has been developed. Embryogenic callus cultures were established from mature seeds, cotyledons and shoot tips on Murashige and Skoog (MS) medium containing $87.64 \mu M$ sucrose, $0.8 \%$ agar, 2,4-dichlorophenoxyacetic acid 2,4-D and kinetin. Maximum callus induction $(94 \%, 92 \%)$ was observed in cotyledons and mature seeds on MS medium supplemented with $1 \mathrm{mg} / \mathrm{L} 2,4-D$, respectively. Somatic embryos were observed on mature seed explants after 17 weeks on MS medium supplemented with $5 \mathrm{mg} / \mathrm{L} 2,4-D \quad(33 \%)$ and $0.5 m g / L \quad \alpha$ naphthaleneacetic acid (NAA) (27\%). while somatic embryos were observed on cotyledon explants after 18 weeks on MS medium supplemented with $2 \mathrm{mg} / \mathrm{L}$ 2,4-D (10\%) and $0.5 \mathrm{mg} / \mathrm{L} N A A(25 \%)$. The highest percentage of somatic embryogenesis (40\%) was obtained with 2 $\mathrm{mg} / \mathrm{L} 2,4-D$ and $0.5 \mathrm{mg} / \mathrm{L} N A A(30 \%)$ on shoot tip explants after 13 weeks. Regeneration of adventitious buds from callus of cotyledon and mature seeds were achieved after 8 weeks on MS medium supplemented with $0.5 \mathrm{mg} / \mathrm{L}$ and $1 \mathrm{mg} / \mathrm{L}$ 6-benzyladenine (BA), respectively. In vitroregenerated plantlets with well-developed roots were successfully hardened in a greenhouse and established in soil.

Generally, auxin was found critical for induction of callus and formation of somatic embryos, while the cytokinin was essential for callus differentiation and plant regeneration.

Key words: Cucumber; cytokinin; somatic embryogenesis; cotyledon, callus, Cucumis sativus L., shoot tip.

\section{INTRODUCTION}

Cucumber (Cucumis sativus L.) is an important species of Cucurbitaceae and, with the exception of watermelon, is cultivated more than any other 
cucurbit in worldwide. Cucumber supply human with edible products and useful fibers (Bisognin, 2002).

Micropropagation and shoot regeneration protocols for cucumber are required to decrease the cost of hybrid seed production which is usually higher than $30 \%$ of total seedling cost (Konstas and Kintzios, 2003). A high frequency of variation in regenerated plants occurs at the callus or somatic embryo stage (Malepszy and Nadolska-Orczyk, 1989). An efficient regeneration system via somatic embryogenesis can be used for artificial seed production and genetic transformation (Nakagawa et al., 2001). Somatic embryos have been induced from various cucumber explants such as cotyledons, hypocotyls, petioles, and leaves (Jia et al., 1986; Ladyman and Girard, 1992; Lou and Kako, 1994; Burza and Malepszy, 1995; Lou et al., 1996; and Nakagawa et al., 2001). A high frequency of somatic embryos was induced in MS liquid medium supplemented with $4.52 \mu \mathrm{M}$ 2,4-D and $10 \%$ coconut water. MS medium supplemented with $87.64 \mathrm{mM}$ sucrose and $0.34 \mathrm{mM}$ glutamine promoted higher somatic embryo production whereas cytokinin had no effect and led to recallusing of embryos. About 8-10\% of embryos converted into plants (Hassanein, 2003 and Vengadesan et al., 2005). Somatic embryos were obtained when auxin was available in the induction phase and the number of embryos were reduce in the absence of cytokinin and the number of somatic embryos increased with sucrose concentration to a maximum of 9\% sucrose (Suliman Elmeer and Hennerty, 2007). Regeneration of cucumber plants have been reported with limited success either directly or indirectly on various explants (Ziv and Gadasi, 1986). These include cotyledons (Trulson and Shahin, 1986), leaves (Malepszy and NadolskaOrczyk, 1983), shoot tip culture (Vasudevan et al., 2004; 2008), and embryonal axis (Vasudevan et al., 2007). Embryo differentiation was achieved on Gamborg's (B5) medium supplemented with $0.25 \mu \mathrm{M}$ NAA, $0.25 \mu \mathrm{M}$ kinetin and 0.09M sucrose (Ashok Kumar and Murthy, 2004). Optimum shoot regeneration was observed on MS medium containing $1.0 \mu \mathrm{M}$ BA and $200 \mathrm{mg} / \mathrm{L}$ casein hydrolysate (Naseem and Anis, 2005). Regeneration of adventitious buds from callus (25 shoots per explant) was achieved on MS medium supplemented with $8.88 \mu \mathrm{M}$ BA, $2.5 \mu \mathrm{M}$ zeatin and $10 \%$ coconut water after two subcultures in the same medium at 30 days interval (Selvaraj et al., 2006). Shoot tip explants (3 to $5 \mathrm{~mm}$ length) from 13 day-old in vitro grown seedlings were cultured on MS medium supplemented with different BA and NAA concentrations $(0.0,0.3,0.4$ and $0.6 \mu \mathrm{M}$ ) and their combinations for shoot proliferation on 32 days (Mohammadi and Sivritepe, 2007 ). The highest frequency of adventitious shoot regeneration (42.8\%) was obtained on MS medium with $1.0 \mathrm{mg} / \mathrm{L} \mathrm{BA}+$ $0.25 \mathrm{mg} / \mathrm{L}$ indole-3-acetic acid (IAA) from the seeds germinated under dark condition (Mendi et al., 2010). Calli induced in leaf disc on the highest level of $5 \mathrm{mg} / \mathrm{L} \mathrm{2,4-D}$ yielded the highest embryo formation (23\%) whereas calli induced 
on $N^{6}$ benzlaminopurine (BAP) and BAP $+\mathrm{NAA}(5+1 \mathrm{mg} / \mathrm{L})$ regenerated into (14\% and 12\%)shoots, respectively (Usman et al., 2011). Recent attention has been directed towards gene transformation technology as a way of introducing heterogeneous genes into cucumber without the limits of cross incompatibility between species. Most of the studies dealt with indirect plant regeneration and genetic transformation systems which depend on some form of plant regeneration technology.

Therefore, the objective of the current study was to optimize efficient regeneration of cucumber plants from embryogenic calli and to investigate the influence of explant source, plant growth regulators on somatic embryogenesis and embryogenic callus differentiation.

\section{MATERIALS AND METHODS}

\section{Seeds and media sterilization procedures:}

Seeds of Cucumis sativus cv, Faris were provided by Indo-American Hybrid seeds, Bangalore, India. Seeds were soaked for $15 \mathrm{~min}$ in distilled water to render germination uniform, surface-sterilized with 5\% Sodium hypochlorite (Clorox) for $20 \mathrm{~min}$ and rinsed three times with distilled water. The MS medium (pH 5.8) with vitamins, $3 \%$ sucrose and $0.8 \%$ agar was autoclaved at $\left(121^{\circ} \mathrm{C}\right)$ for $20 \mathrm{~min}$.

\section{Explant derived from mature seeds, cotyledons and shoot tips:}

Sterilized seeds were cut transversely into two unequal sections; one section (embryonic axis and one-third of the cotyledon) was eliminated and the remaining two sections (two thirds of cotyledons) were used. The cotyledon and shoot tip explants were excised from seedling grown on MS ( Murashige and Skoog , 1962 ) medium for 7-9 days. Cotyledon divided into 1-cm pieces and the apices of shoot tips were cut into longitudinal halves. All explants were cultured horizontally on the MS induction medium in total darkness at $25 \pm 2{ }^{\circ} \mathrm{C}$.

\section{Callus induction medium}

In order to investigate the influence of different auxin and cytokinins on induction and fresh weight of callus, the mature seed and cotyledon explants were cultured on MS medium supplemented with 2,4 dichlorophenoxy acetic acid (2,4-D at 1.0, 2.0 and $5.0 \mathrm{mg} / \mathrm{L})$ alone or in combination with kinetin ( 0.5 , 1.0 and $2.0 \mathrm{mg} / \mathrm{L}$ ). Control cultures were initiated on MS medium without growth regulators.

\section{Induction of somatic embryogenesis:}

After 4-5 weeks, callus from mature seed, cotyledon and shoot tip explants were transferred on MS medium in two experiments, the first supplemented with 2,4-D (1.0, 2.0 and 5.0mg/L) alone or in combination with kinetin $(0.5,1.0$ and 
$2.0 \mathrm{mg} / \mathrm{L}$ ) and the second supplemented with naphthalene acetic acid ( NAA at $0.1,0.2$ and $0.5 \mathrm{mg} / \mathrm{L}$ ) and benzyl adenine ( BA at $0.5,1.0$ and $2.0 \mathrm{mg} / \mathrm{L}$ ) each alone or in combination to induce somatic embryogenesis.

\section{Callus differentiation:}

Embryogenic callus from mature seed and cotyledon explants were transferred and re-cultured on MS medium supplemented with BA $(0.5,1.0$ and $2.0 \mathrm{mg} / \mathrm{L})$ and NAA $(0.1,0.2$ and $0.5 \mathrm{mg} / \mathrm{L})$ each alone or in combination for induction of callus differentiation. Shoot differentiation and induction frequencies were recorded at the 20 days after induction.

\section{RESULTS AND DISCUSSION}

\section{Callus induction:}

After 3 weeks of initial culture on the callus induction medium, calli were observed on cotyledon and mature cutting seeds explants. The results showed that 2, 4-D had the highest effect for induction of callus which was mostly soft, fastly growing, creamy-white and friable. The great significant activity of explants induced callus was at MS medium supplemented with 1.0 and $2.0 \mathrm{mg} / \mathrm{L} \mathrm{2,4-D} \mathrm{(94 \%} \mathrm{and} 92 \%$, respectively) as shown in Table 1 and Figure 1. The highest callus fresh weight (3.01g/culture, compact and Creamy-white) was recorded at 10 weeks on medium containing $1.0 \mathrm{mg} / \mathrm{L} \mathrm{2,4-D} \mathrm{followed} \mathrm{by} 2.0 \mathrm{mg} / \mathrm{L} \mathrm{2,} \mathrm{4-D} \mathrm{(2.97}$ $\mathrm{g}$ /culture). Generally, addition of 2, 4-D at low concentration increased callus induction rate and callus fresh weight Whereas, addition of kinetin or increasing 2, 4-D concentration resulted in decreasing callus induction rate and callus fresh weight as shown in Table 2 and Figure 2. These results are in agreement with Liu et al., (1997) and Ashok Kumar et al., (2006), they found that callus mediated embryogenesis (embryogenic calli with embryos) was induced on B5 medium supplemented with 2, 4-D and NAA alone as well as 2, 4-D in combination with BAP or kinetin or thidiazuron (TDZ). Pall et al., (2007) found that the maximum morphogenic callus induction rate $(86 \%)$ was observed from hypocotyl explants by culturing in MS medium supplemented with $2.5 \mathrm{mg} / \mathrm{L} \mathrm{2,} \mathrm{4-D.}$ Usman et al., (2011) showed that Maximum callus induction $94.16 \%$ and $76 \%$ was observed in leaf disc explants on MS medium supplemented with 2mg/L 2, 4-D, NAA and BAP (1.5 mg/L, each), respectively. Seed cotyledon explants induced maximum calli $(77 \%)$ on $4.0+0.75 \mathrm{mg} / \mathrm{L}$ (BAP+NAA, respectively). 


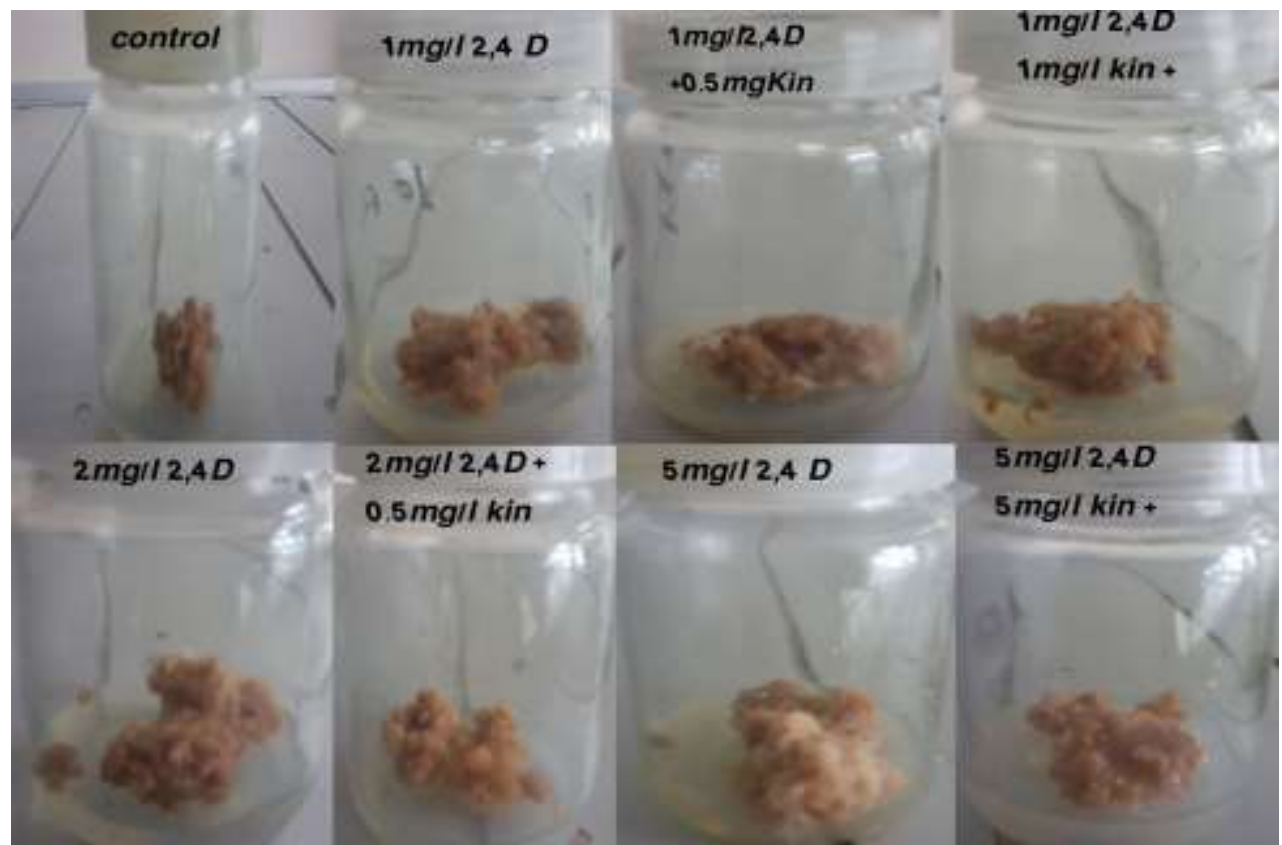

Figure 1. Effect of plant growth regulators (2,4-D and kinetin) on callus formation from cotyledons of cucumber.

Table 2. Effect of 2,4-D and kinetin concentrations on induction of callus using mature seed explants of cucumber.

\begin{tabular}{|c|c|c|c|c|c|c|c|}
\hline \multicolumn{2}{|c|}{$\begin{array}{l}\text { Auxin and cytokinin } \\
\text { conc. } \mathrm{mg} / \mathrm{L}\end{array}$} & \multirow{2}{*}{$\begin{array}{c}\text { No.of } \\
\text { initial } \\
\text { explant }\end{array}$} & \multirow{2}{*}{$\begin{array}{l}\text { No. of } \\
\text { explant } \\
\text { formed } \\
\text { callus }\end{array}$} & \multirow{2}{*}{$\begin{array}{c}\% \text { of } \\
\text { explant } \\
\text { induced } \\
\text { callus }\end{array}$} & \multirow{2}{*}{$\begin{array}{c}\text { Fresh } \\
\text { weight } \\
\text { (gm) }\end{array}$} & \multirow{2}{*}{$\begin{array}{l}\text { Callus } \\
\text { color }\end{array}$} & \multirow{2}{*}{$\begin{array}{c}\text { Callus } \\
\text { type }\end{array}$} \\
\hline $\begin{array}{l}\text { 2,4-D } \\
(\mathrm{mg} / \mathrm{L})\end{array}$ & $\begin{array}{c}\text { Kinetin } \\
(\mathrm{mg} / \mathrm{L})\end{array}$ & & & & & & \\
\hline 0.0 & 0.0 & 50 & 1.0 & 2 & 1.45 & cr & Friable \\
\hline \multirow{4}{*}{1.0} & 0.0 & 50 & 46 & 92 & 2.85 & crw & compt \\
\hline & 0.5 & 50 & 43 & 86 & 2.78 & cr & compt \\
\hline & 1.0 & 50 & 42 & 84 & 1.99 & cr & friable \\
\hline & 2.0 & 50 & 35 & 70 & 1.91 & cr & compt \\
\hline \multirow{4}{*}{2.0} & 0.0 & 50 & 45 & 90 & 2.54 & cr & compt \\
\hline & 0.5 & 50 & 43 & 86 & 2.25 & cr & compt \\
\hline & 1.0 & 50 & 43 & 86 & 1.89 & cr & compt \\
\hline & 2.0 & 50 & 36 & 72 & 1.82 & cr & friable \\
\hline \multirow{4}{*}{5.0} & 0.0 & 50 & 42 & 84 & 2.38 & B & friable \\
\hline & 0.5 & 50 & 41 & 82 & 2.21 & B & friable \\
\hline & 1.0 & 50 & 41 & 82 & 1.57 & LB & friable \\
\hline & 2.0 & 50 & 40 & 80 & 1.54 & LB & friable \\
\hline
\end{tabular}




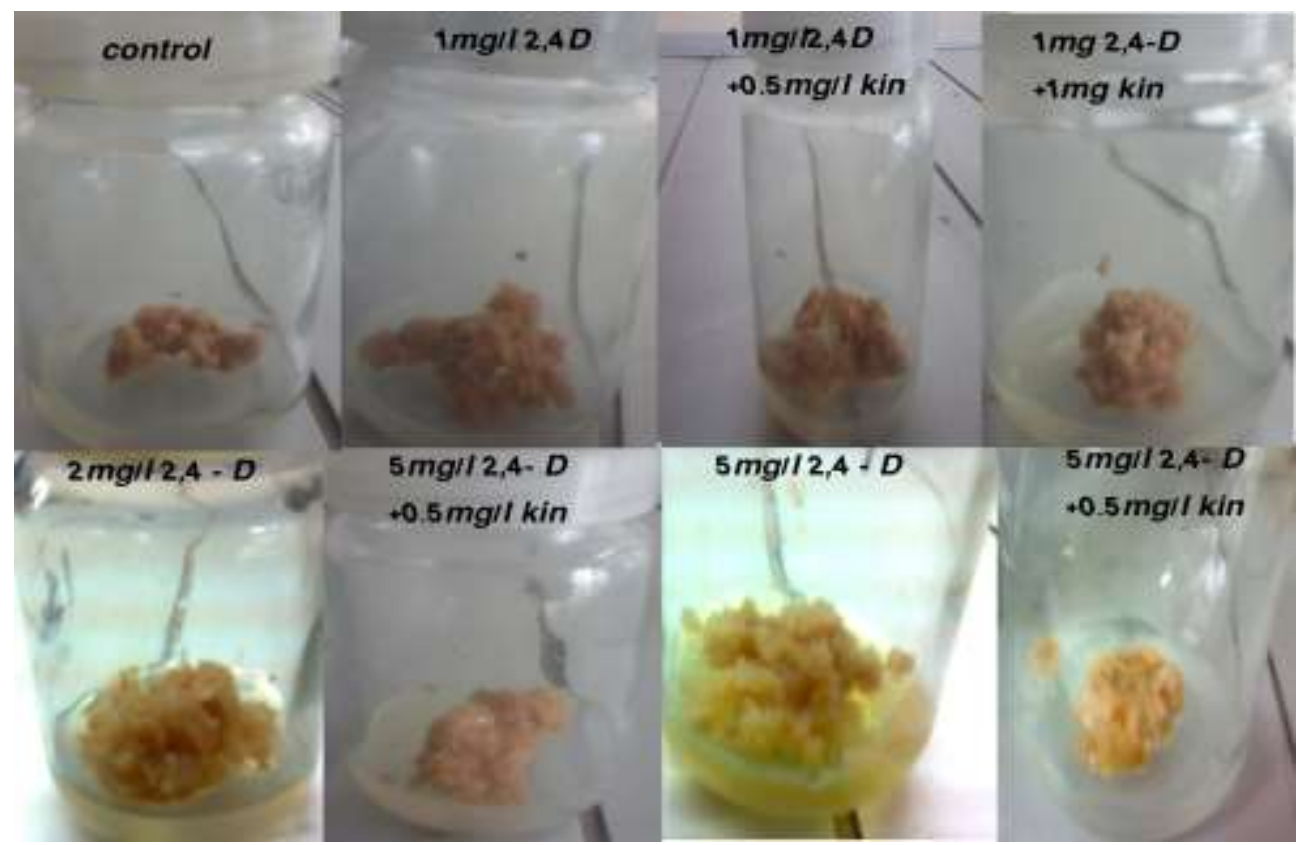

Figure 2. Effect of plant growth regulators (2, 4-D and kinetin) on callus formation from mature seeds of cucumber.

\section{Induction of somatic embryogenesis:}

Mature seed, cotyledon and shoot tip explants were enlarged on the induction medium at day 7-10, the green color of the cotyledon and leaf explants became light green or light brown after 4 weeks, and green color disappeared within 8 to 10 weeks. All explants became brownish after 8 weeks. Formation of somatic embryos was observed on mature seed, shoot tip and cotyledon explants after 17,13 , and 18 weeks, respectively. The best concentration $(5 \mathrm{mg} / \mathrm{L} 2,4-\mathrm{D})$ giving the highest percentage of somatic embryos (33\%) on mature seed explants. Reducing 2, 4-D to $2 \mathrm{mg} / \mathrm{L}$ in the presence or in the absence of the kinetin resulted in decreasing induction of somatic embryos (Table 3).

On other hand, $0.5 \mathrm{mg} / \mathrm{L}$ NAA was the best concentration giving the high percentage of embryogenesis (27\%). The addition of BA resulted in decreasing of somatic embryos, while increasing BA above $0.5 \mathrm{mg} / \mathrm{L}$ in the presence or absence of NAA resulted in no induction of somatic embryos (Table 4). For the cotyledon explants, $2 \mathrm{mg} / \mathrm{L} \mathrm{2,4-D}$ was the best concentration giving the highest percentage of embryogenesis $(10 \%)$ whereas, adding of kinetin at $2 \mathrm{mg} / \mathrm{L}$ in combination did not produce any somatic embryos (Table 3 ). Increasing 2, 4-D concentration from 2 to $5 \mathrm{mg} / \mathrm{L}$ resulted in decreasing the induction of somatic embryos (Table 3). On other hand, $0.5 \mathrm{mg} / \mathrm{L}$ NAA was the best concentration giving the highest percentage of embryogenesis (25\%). The addition of BA resulted in no induction of somatic embryogenesis (Table 4). 


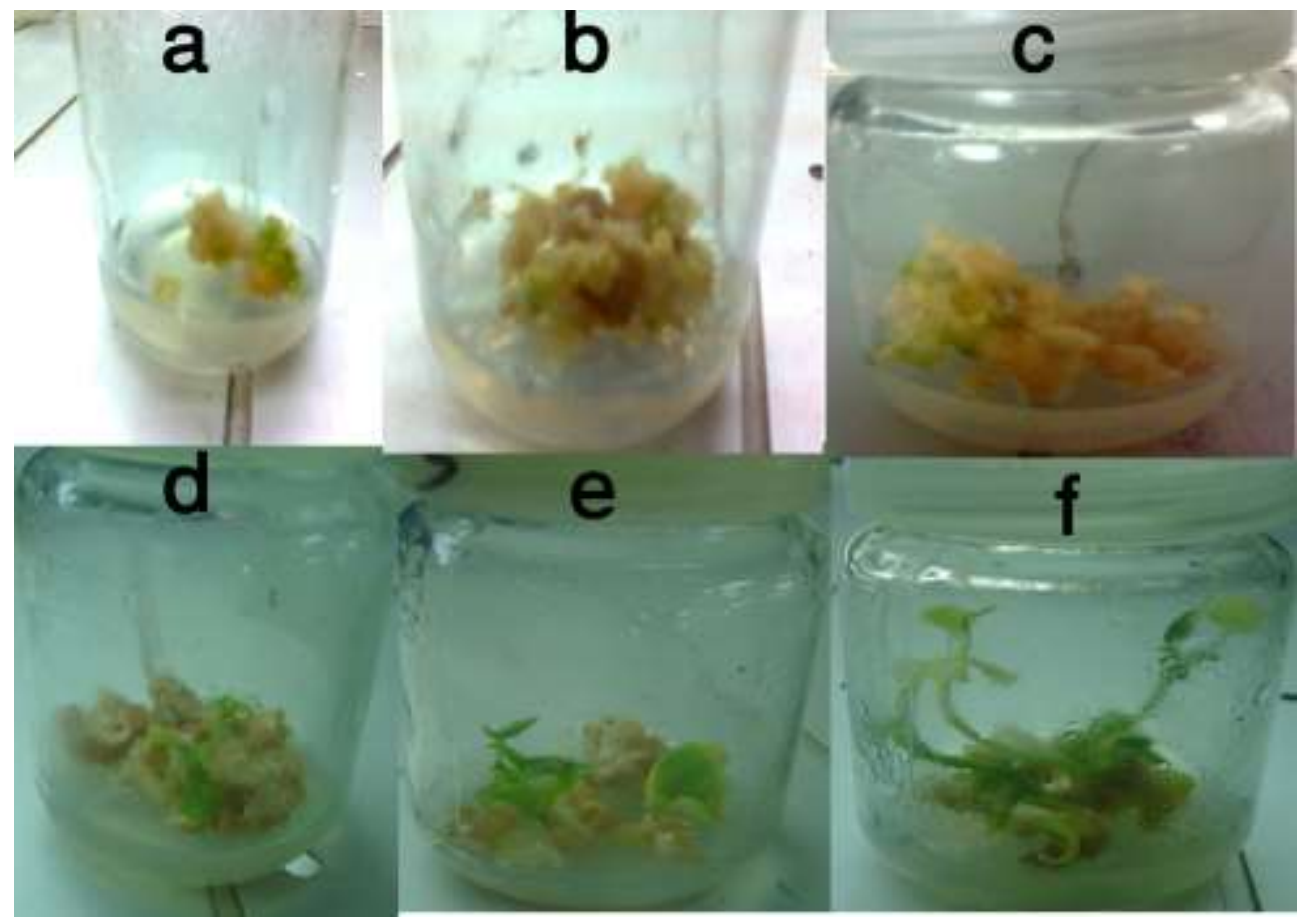

Figure 3. Development of somatic embryos and plant regeneration, (a, b, and c) formation of somatic embryos on mature seed, leaf and shoot tip explants, respectively. (d, e and f) conversion and germination of somatic embryos after exposing to light/dark 16/8h for one, two and 3 weeks, respectively

In case of shoot tip explants, The highest percentage of somatic embryogenesis (40\%) was obtained with $2 \mathrm{mg} / \mathrm{L} 2$, 4-D. while, increasing 2, 4-D concentration to $5 \mathrm{mg} / \mathrm{L}$ resulting in decreasing the induction of somatic embryos. Adding of kinetin $(2 \mathrm{mg} / \mathrm{L})$ in combination with 2 , 4-D led to significantly decreasing somatic embryos percentage and addition of kinetin in combination with $2,4-\mathrm{D}(5 \mathrm{mg} / \mathrm{L})$ resulted in no induction of the somatic embryogenesis (Table 3). On other hand, the highest percentage of somatic embryogenesis $(30 \%)$ was obtained with $0.5 \mathrm{mg} / \mathrm{L}$ NAA, followed by $0.2 \mathrm{mg} / \mathrm{L}$ NAA (Table 4). The addition of BA resulted in decreasing of induction of somatic embryogenesis. The increasing concentration of BA above $0.5 \mathrm{mg} / \mathrm{L}$ in combination with NAA or absence results in no induction of somatic embryogenesis. Overall, increasing the auxins concentration or adding the cytokinins had negative effect on the induction of somatic embryos in cotyledon explants as shown in Figure 3.

These data are in agreement with Trulson and Shahin (1986), Tabei et al., (1994), Hassanein (2003), and Vengadesan et al., (2005), they found the Somatic embryogenesis was induced on a medium consisting of MS salts supplemented with 2, 4-D, NAA and BA. Embryos matured on the same medium without 2, 4- 
D, and developed into normal plants on a hormone-free MS medium. Suliman Elmeer and Hennerty (2007) showed that somatic embryos were obtained when auxin was available in the induction phase and the number of embryos was reducing in the absence of cytokinin. The number of somatic embryos increased with sucrose concentration to a maximum of $9 \%$ sucrose. Three weeks on induction medium was needed for production of somatic embryos; prolonged incubation (6 weeks) gave poor somatic embryo numbers.

\section{Induction of callus differentiation:}

In regard to cotyledon explants, the best concentration for callus differentiation percentage (67 and 50) was recorded with 0.5 and $1.0 \mathrm{mg} / \mathrm{L} \mathrm{BA}$, respectively. The addition of NAA in combination with BA resulted in decreasing the induction of callus differentiation (Table 5 and Figure 4 ). $1.0 \mathrm{mg} / \mathrm{L} \mathrm{BA}$ was the most effective to produce the highest significant value of shoot number per explant (5), followed by $0.5 \mathrm{mg} / \mathrm{L}$ BA (3). Increasing the concentration of BA above 1.0 $\mathrm{mg} / \mathrm{L}$ resulted in decreasing the percentage of callus differentiation (7) and number of shoots per explant (1). $1.0 \mathrm{mg} / \mathrm{L} \mathrm{BA}$ was the most effective to produce the highest of leaf number per explant (15), followed by (0.5 BA, $0.5 \mathrm{BA}+0.1 \mathrm{NAA}$, 1.0 BA + 0.1 NAA and 1.0 BA + 0.1mg/L NAA) (6).

Table 5. Effect of NAA and BA concentrations on induction of callus differentiation using leaf cotyledon explants of cucumber.

\begin{tabular}{|c|c|c|c|c|c|c|}
\hline \multirow{2}{*}{\multicolumn{2}{|c|}{$\begin{array}{c}\text { Growth regulator } \\
\begin{array}{c}\text { Auxin and cytokinin } \\
\text { conc. }\end{array}\end{array}$}} & \multirow{3}{*}{$\begin{array}{l}\text { No of } \\
\text { Initial } \\
\text { explant }\end{array}$} & \multirow{3}{*}{$\begin{array}{l}\text { No. of Explant } \\
\text { produced } \\
\text { organogenesis }\end{array}$} & \multirow{3}{*}{$\begin{array}{c}\text { Regeneration } \\
\text { percentage }\end{array}$} & \multirow{3}{*}{$\begin{array}{c}\text { Shoot } \\
\text { number }\end{array}$} & \multirow{3}{*}{$\begin{array}{c}\text { Leaf } \\
\text { number }\end{array}$} \\
\hline & & & & & & \\
\hline $\begin{array}{c}\text { NAA } \\
(\mathbf{m g} / \mathbf{L})\end{array}$ & $\begin{array}{c}\mathbf{B A} \\
(\mathrm{mg} / \mathrm{L})\end{array}$ & & & & & \\
\hline 0.0 & 0 & 30 & - & - & - & - \\
\hline 0.1 & \multirow{3}{*}{ 0 } & 30 & - & - & - & - \\
\hline 0.2 & & 30 & - & - & - & - \\
\hline 0.5 & & 30 & - & - & - & - \\
\hline 0.0 & \multirow{4}{*}{0.5} & 30 & 20 & 67 & 3 & 6 \\
\hline 0.1 & & 30 & 2 & 7 & 2 & 6 \\
\hline 0.2 & & 30 & - & - & - & - \\
\hline 0.5 & & 30 & - & - & - & - \\
\hline 0.0 & \multirow{4}{*}{1} & 30 & 15 & 50 & 5 & 15 \\
\hline 0.1 & & 30 & 9 & 30 & 2 & 6 \\
\hline 0.2 & & 30 & 6 & 20 & 2 & 6 \\
\hline 0.5 & & 30 & - & - & - & - \\
\hline 0.0 & \multirow{4}{*}{2} & 30 & 2 & 7 & 1 & 4 \\
\hline 0.1 & & 30 & - & - & - & - \\
\hline 0.2 & & 30 & - & - & - & - \\
\hline 0.5 & & 30 & - & - & - & - \\
\hline
\end{tabular}




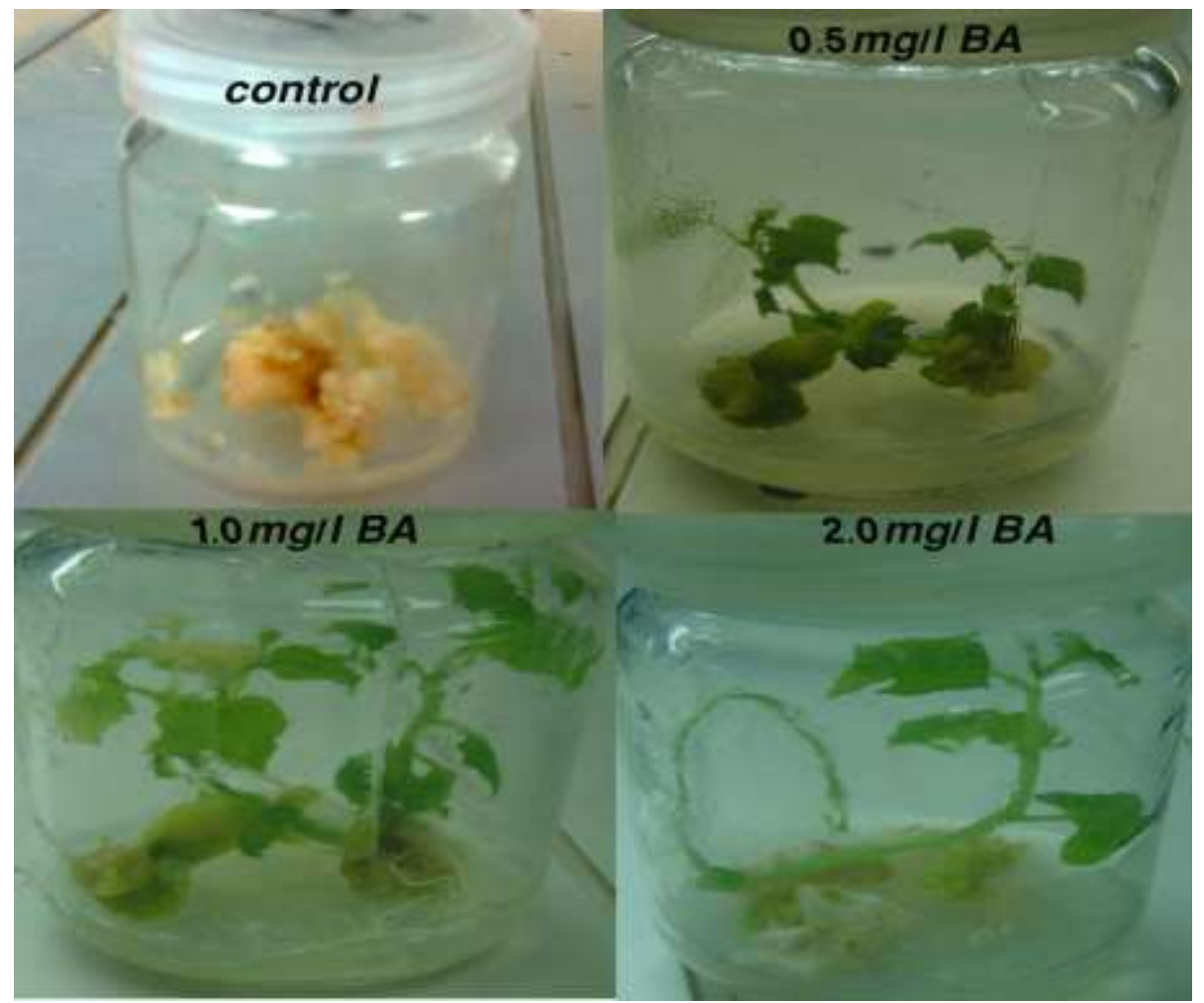

Figure 4. Effect of different concentrations of BA on callus differentiation and plant regeneration from cotyledon of cucumber.

In case of callus from mature seed, the best concentration for callus differentiation percentage (50 and 30) and highest significant value of shoot number per explants $(6,3)$ was recorded with 1.0 and $0.5 \mathrm{mg} / \mathrm{L}$, respectively. $1.0 \mathrm{mg} / \mathrm{L} \mathrm{BA}$ was the most effective to produce the highest significant value of leaf number per explants (10), followed by $(1.0 \mathrm{BA}+$ $0.1 \mathrm{NAA}$ and $1.0 \mathrm{BA}+0.1 \mathrm{mg} / \mathrm{L}$ NAA) (6) as shown in Table 6 and Figure 5. Generally the addition of NAA in combination with BA resulted in decreasing the induction of callus differentiation, shoot number and leaf number per explant. These results are in agreement with Selvaraj et al., (2006), they found the regeneration of adventitious buds from callus (25 shoots per explant) was achieved on MS medium supplemented with 8.88 $\mu \mathrm{M}$ BA, $2.5 \mu \mathrm{M}$ zeatin and $10 \%$ coconut water after two subcultures in the same medium at 30-day interval. Rakhi et al., (2010) reported that the adventitious shoot development was largely dependent on the genotype and the type and concentrations of cytokinin. Presence of BA either alone or in combination with 6-(y, y-dimethylallylamino) purine (2iP) proved to be essential for direct, as well as, indirect shoot regeneration in cucurbits. 
Table 6. Effect of NAA and BA concentrations on induction of callus differentiation using mature seed explants of cucumber.

\begin{tabular}{|c|c|c|c|c|c|c|}
\hline \multirow{2}{*}{\multicolumn{2}{|c|}{$\begin{array}{l}\text { Growth regulator } \\
\text { Auxin and cytokinin } \\
\text { conc. }\end{array}$}} & \multirow{3}{*}{$\begin{array}{c}\text { No of } \\
\text { Initial } \\
\text { explant }\end{array}$} & \multirow{3}{*}{$\begin{array}{l}\text { No. of Explant } \\
\text { produced } \\
\text { organogenesis }\end{array}$} & \multirow{3}{*}{$\begin{array}{c}\text { Regeneration } \\
\text { percentage }\end{array}$} & \multirow{3}{*}{$\begin{array}{c}\text { Shoot } \\
\text { number }\end{array}$} & \multirow{3}{*}{$\begin{array}{c}\text { Leaf } \\
\text { number }\end{array}$} \\
\hline & & & & & & \\
\hline $\begin{array}{c}\text { NAA } \\
(\mathbf{m g} / \mathbf{L})\end{array}$ & $\begin{array}{c}\text { BA } \\
(\mathrm{mg} / \mathrm{L})\end{array}$ & & & & & \\
\hline 0.0 & 0.0 & 30 & - & - & - & - \\
\hline 0.1 & \multirow{3}{*}{0.0} & 30 & - & - & - & - \\
\hline 0.2 & & 30 & - & - & - & - \\
\hline 0.5 & & 30 & - & - & - & - \\
\hline 0.0 & \multirow{4}{*}{0.5} & 30 & 10 & 30 & 3 & 6 \\
\hline 0.1 & & 30 & - & - & - & - \\
\hline 0.2 & & 30 & - & - & - & - \\
\hline 0.5 & & 30 & - & - & - & - \\
\hline 0.0 & \multirow{4}{*}{1.0} & 30 & 15 & 50 & 6 & 10 \\
\hline 0.1 & & 30 & 4 & 13 & 2 & 8 \\
\hline 0.2 & & 30 & 6 & 20 & 2 & 8 \\
\hline 0.5 & & 30 & - & - & - & - \\
\hline 0.0 & \multirow{4}{*}{2.0} & 30 & - & - & - & - \\
\hline 0.1 & & 30 & - & - & - & - \\
\hline 0.2 & & 30 & - & - & - & - \\
\hline 0.5 & & 30 & - & - & - & - \\
\hline
\end{tabular}

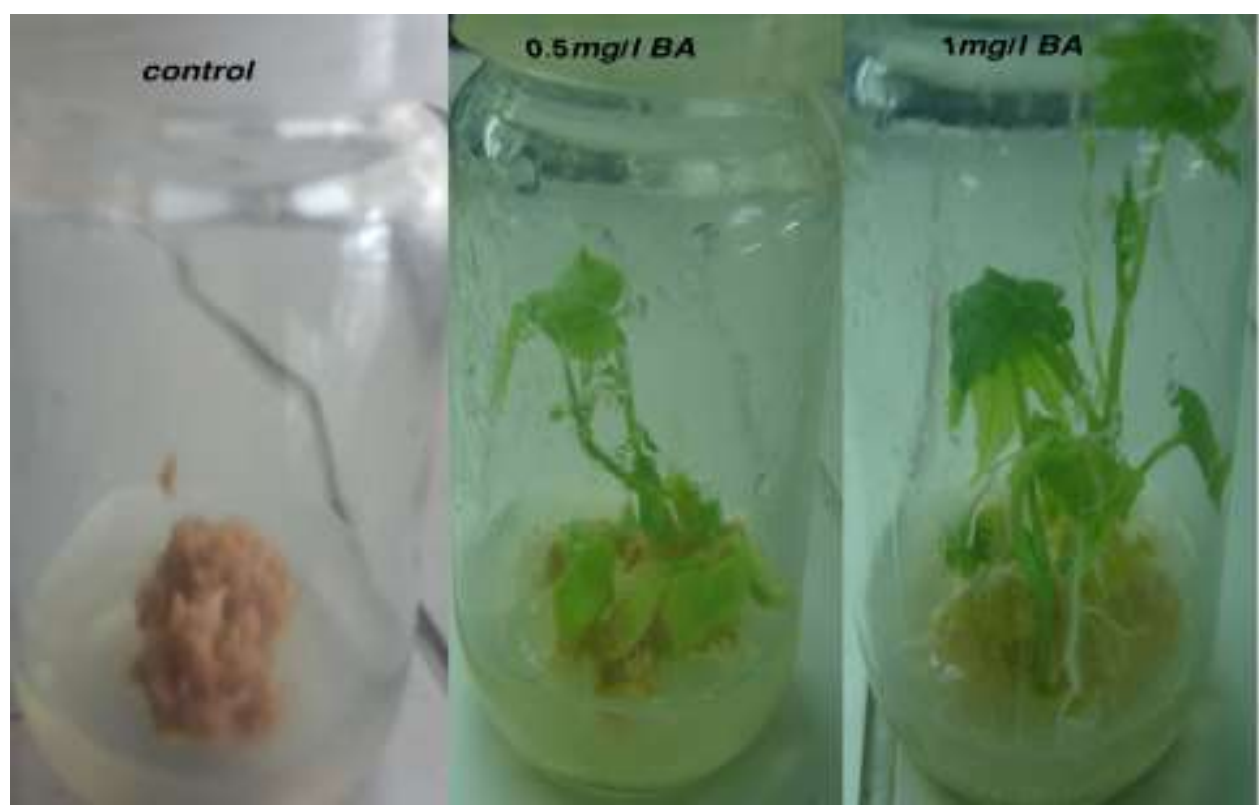

Figure 5. Effect of different concentrations of BA on callus differentiation and plant regeneration from mature seeds of cucumber. 
In conclusion, the present study showed that lowest auxin concentration was found critical for callus induction rate, callus fresh weight and formation of somatic embryos. In addition, callus differentiation and plant regeneration were strongly affected by cytokinin.

\section{REFERENCE}

Ashok Kumar, H. G. and H. N., Murthy. 2004. Effect of sugars and amino acids on androgenesis of Cucumis sativus. Biomedical and Life Sciences 78: 201-208.

Ashok Kumar, H. G., H. N., Murthy and K. Y., Paek. 2006. Embryogenesis and plant regeneration from anther cultures of Cucumis sativus L. Sci. Hort. 98: 213-222.

Bisognin, D.A. 2002. Origin and evolution of cultivated cucurbits. Ciencia Rural. 32: 715-723.

Burza, W. and S. Malepszy. 1995. In vitro culture of Cucumis sativus L. XVIII. Plants from protoplasts through direct somatic embryogenesis. Plant Cell, Tissue and Organ Culture 41: 259-266.

Gamborg, O.L., R.A. Miller. and K. Ojima. (1968). Exp. Cell Res. 50: $151-158$

Hassanein, A. M. (2003). Somatic Embryogenesis of Cucumber (Cucumis sativus L) using seed cuttings obtained from pre-mature fruit. Plant Biotechnol, 275-281.

Jia, S.R., Y.Y. Fu and Y. Lin. 1986. Embryogenesis and regeneration from cotyledon protoplast culture of cucumber (Cucumis sativus L.). Plant Physiol. 124:393-398.

Konstas, J. and S. Kintzios, 2003. Developing a scale-up system for the micropropagation of cucumber (Cucumis sativus L.): The effect of growth retardants, liquid culture and vessel size. Plant Cell Rep. 21: 538-548.

Ladyman, A. R. J. and B. Girard. 1992. Cucumber somatic embryo development on various gelling agents and carbohydrates source. Sci. Hort. 27:164-165.

Liu, Z., W. Wang and S. Yan. 1997. Effect of hormone treatment on callus formation and endogenous indole-acetic acid and polyamine content of soybean hypocotyl cultivate in vitro. Bot. Pull. Acad. Sin. 38:171-176.

Lou, H. and S. kako. 1994. Somatic embryogenesis and plant regeneration in cucumber. Sci. Hort. 29: 906-909.

Lou, H. Z., P. Obara-Okayo, M. Tamaki, and S. S. Kako. 1996. Influence of sucrose concentration on in vitro morphogenesis in cultured cucumber cotyledon explants. Sci.Hort. 71:497-502. 
Malepszy, S. and A. Nadolska-Orczyk. 1983. In vitro culture of Cucumis sativus L. Regeneration of plantlets from callus formed by leaf explants. Pflanzenphysiol. 111: 273-276.

Malepszy, S. and A. Nadolska-Orczyk. 1989. In vitro culture of Cucumis sativus VIII. Variation in the progeny of phenotypically not altered R1 plants. Plant Breeding. 102: 66-72.

Mendii, Y.Y., N. Comlekcioglu2, M. Ipek3, E. Kocamani, T. izgui, D. Tekdal1 and P. Curuk1. 2010. The effect of different hormone concentrations and dark pretreatment on adventitious shoot regeneration in snake melon (Cucumis melo var. flexousus). Romanian Biotechnological Letters., 15 (4).

Mohammadi, J. and N. Sivritepe 2007. In vitro clonal propagation of cucumis sativus L. by shoot tip culture. J Biol. Sci. 7: 653-657.

Murashige, T. and F. Skoog. 1962. A revised medium for rapid growth and bio assays with tobacco tissue cultures. Plant Physiol. 15: 473-497.

Nakagawa, H., T. Saijyo, N. Yamauchi, M. Shigyo, S. Kako and A. Ito. 2001. Effects of sugars and abscisic acid on somatic embryogenesis from melon (Cucumis melo L.) expanded cotyledon. Sci. Hort. 90: 85-92.

Naseem, A. and M. Anis. 2005. In vitro Mass Propagation of Cucumis sativus L., from Nodal Segments. Turk. J. Bot. 29: 237-240.

Pall, S. P., I. Alam1, M. Anisuzzaman, K. K.Sarker, S. A. Sharmin, M. F. Alam. 2007. Indirect organogenesis in summer squash (Cucurbita pepo L.). Turk. J. Agric. 31: 63-70.

Rakhi, C., H. R. Rekha and M. V. Kumar. (2010). Assessment of regenerative potentiality of cotyledon explants of some indigenous varieties of cucurbits using varied concentrations of cytokinins. Plant Tissue Cul. \& Biotech. Dhaka, Bangladesh. 27-40.

Selvaraj, N., A. Vasudevan, M. Manickavasagam and A. Ganapathi. 2006. In vitro organogenesis and plant formation in cucumber. Biologia Plantarum. 50:123-126.

Suliman Elmeer, K.M. and M.J. Hennerty. 2007. Genetically stable somatic embryos of $\mathrm{F} 1$ cucumber (Cucumis sativus) hybrids. Acta Hort. 764: 49-56.

Tabei, Y.; Nishio, T.; Kurihara, K.; Kanuo, T. (1994). Selection of transformed callus in a liquid medium and regeneration of transgenic plants in cucumber (Cucumis sativus L.). Breed. Sci. 44: 47-51.

Trulson, A.J. and E.H. Shahin. 1986. In vitro plant regeneration in the genus Cucumis. Plant Sci. 47: 35-43. 
Usman, M., Z. Hussain and B. Fatima. 2011. Somatic embryogenesis and shoot regeneration induced in cucumber leaves. Pak. J. Bot. 43: 12831293.

Vasudevan, A., N. Selvaraj, A. Ganapathi, C.W. Choi, M. Manickavasagam and S. Kasthurirengan. 2007. Direct plant regeneration from cucumber embryonal axis. Biol. Plant. 3: 521-524.

Vasudevan, A., N. Selvaraj, A. Ganapathi, S. Kasthurirengan, V. Ramesh Anbazhagan and M. Manickavasagam. 2004. Glutamine: a suitable nitrogen source for enhanced shoot multiplication in Cucumis sativus L. Biol. Plant. 3: 125-128.

Vasudevan, A., N. Selvaraj, A. Ganapathi, S. Kasthurirengan, V. Ramesh Anbazhagan, M. Manickavasagam and C.W. Choi. 2008. Leucine and spermidine enhance shoot differentiation in cucumber (Cucumis sativus L.). In vitro Cell. Dev. Biol. Plant. 44: 300-306.

Vengadesan, G., R. Prem Anand, N. Selvaraj, R. Perl-Treves and A. Ganapathi. 2005 . Transfer and expression of npt II and bar genes in cucumber (Cucumis sativus L.). In Vitro cell. Dev. Biol. Plant. 41: 1721.

Ziv, M. and G. Gadasi. 1986. Enhanced embryogenesis and plant regeneration from cucumber (Cucumis sativus L.) callus by activated charcoal in solid/liquid double layer cultures. Plant Sci. 47: 115-122. 


\section{استخثاث الاجنة الجسدية وانتاج النباتات من البذور الناضجة، القلقات والقمم النامية للخيار اسماء الباحثين وعناوينهم}

لقد تم استكثاف الأصناف التجارية للخيار لمرحلة التطور الجنيني، وانتاج النباتات في

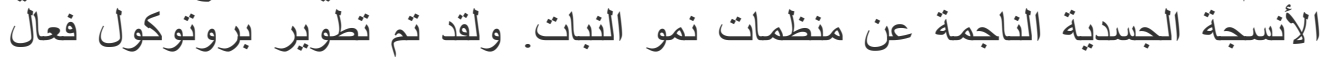
لانتاج نباتات الخيار معمليا عبر الأجنة الجسدية.

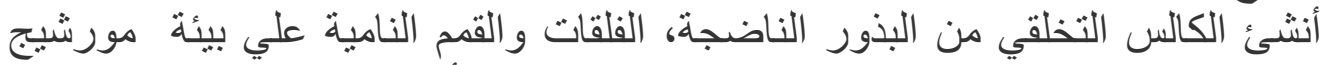

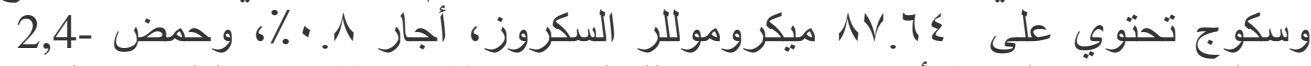

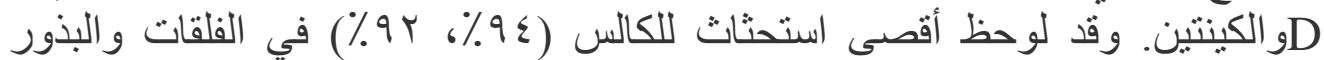

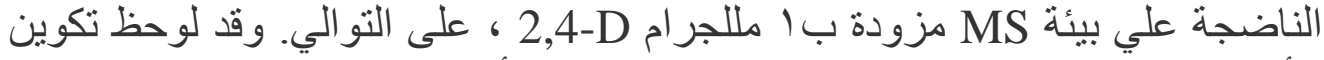

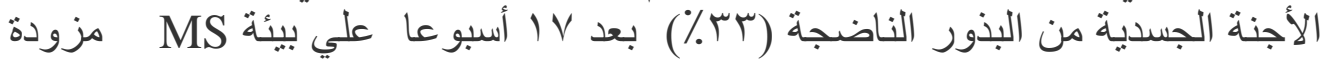

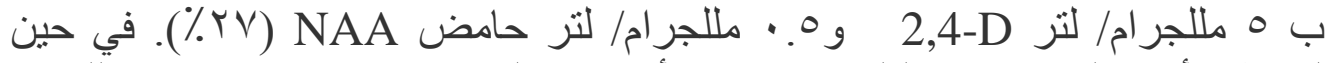

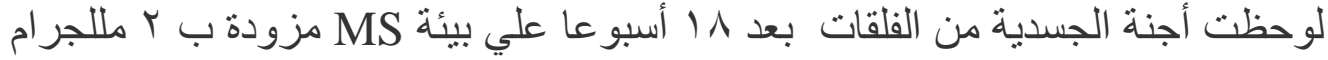

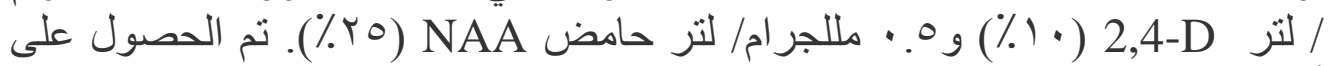

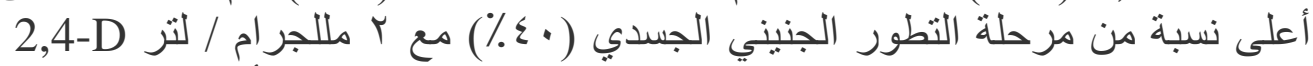

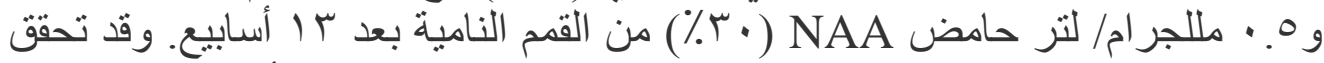

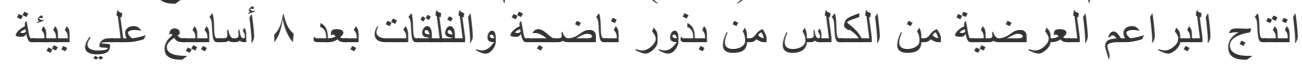

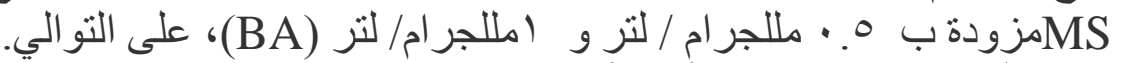

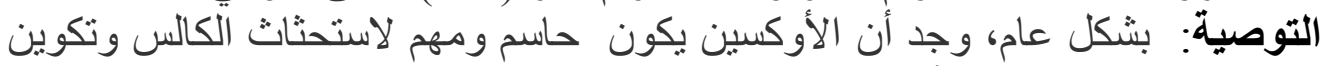
الاجنة الجسدية، في حين أن سيتوكاينين ضروري التين لتمييز الكالس و انتاج النباتات. 